\title{
Neopragmatism Viewed by Pragmaticism
}

A Redescription

Ivo Assad Ibri

\section{(2) OpenEdition Journals}

Electronic version

URL: http://journals.openedition.org/ejpap/607

DOI: $10.4000 /$ ejpap.607

ISSN: 2036-4091

Publisher

Associazione Pragma

\section{Electronic reference}

Ivo Assad Ibri, « Neopragmatism Viewed by Pragmaticism », European Journal of Pragmatism and American Philosophy [Online], V-1 | 2013, Online since 16 July 2013, connection on 04 May 2019. URL http://journals.openedition.org/ejpap/607 ; DOI : 10.4000/ejpap.607

This text was automatically generated on 4 May 2019.

\section{(c) $($ ) $\odot$ (8)}

Author retains copyright and grants the European Journal of Pragmatism and American Philosophy right of first publication with the work simultaneously licensed under a Creative Commons AttributionNonCommercial-NoDerivatives 4.0 International License. 


\title{
Neopragmatism Viewed by Pragmaticism
}

\author{
A Redescription
}

Ivo Assad Ibri

\begin{abstract}
"Nominalists see language merely as signs and sounds used by human beings. One of the things we want to do with language is to get food, another is to get sex, and yet another is to understand the origin of the universe,"

Rorty, EHO, 127.

"Nominalism is a deadly poison to any living thought,"

Peirce, NEM 3, 201.
\end{abstract}

\section{Introduction}

Those who are familiar with Peircean philosophy will soon realize, after a brief perusal of some of the better-known texts of Richard Rorty, that they have entered a universe, as far as their presuppositions are concerned, totally contrary to those adopted by Peircean philosophy. This universe is designed under various conceptual points, which we will call "neo-pragmatist theses," namely:

A. refutation of the concept of representation for its alleged association to 'non-human fixed essences';

B. denial of the possibility of truth as correspondence, for which he uses the 'mirror of Nature' metaphor. ${ }^{1}$ This thesis is evidently closely linked to the previous one;

C. replacement of the concept of discovery by that of invention;

D. defense of nominalism in the face of a metaphysical realism;

E. denial of the role of language as a medium between subject and object; 
F. introduction of the term 'redescription' in lieu of fixed truths, contemplating the factual contingency of human life.

G. attribution to language of the essential role of tool with which solidarity is forged within a democratic society - constituted, as such, of citizens who freely express their ideas - seeking to mitigate human pain and cruelty;

H. replacement of philosophy by literature, as a more efficient tool for the development of people for the exercise of their solidarity-creating language.

I. proposition of the term 'irony,' to define an anti-essentialist, desacralized philosophical attitude that abdicates from argumentations based on truth in favor of a more efficient vocabulary for the discussion of ideas. Rortyan pragmatists are self-defined 'ironists' ( $p$. 136-45 CIS).

2 To all who adopt these viewpoints, notwithstanding their rather summarized presentation, Rorty called pragmatists, declaring himself a particular follower of the tradition of the pragmatist thought of Dewey and James.

Rorty also lists some other traditional names for support, albeit partial, of his theses, such as Kant, Hegel, Heidegger, Derrida, and Wittgenstein. References to Peirce are very topical, evidencing a poor reading of Peircean works, restricted to a few texts of his youth.

4 That collection of Rortyan theses would suffice, I guess, for a serious scholar of Peircean works to suggest his exclusion from the roster of those who agree to take part in the group that Rorty calls frequently in his writings, 'we pragmatists...' In addressing some of the points of discord between Peirce and Rorty, I will endeavor to justify the reason for this exclusion. I will examine, in general, as befits the limited space of this article, some of these theses, and try to explain what a critical position would be, based on Peirce's philosophy. It must be pointed out, however, that none of the Rortyan theses, as detailed above, are admissible within the context of Peirce's system of ideas and, for this reason, to continue using the term 'pragmatism' to designate two, wholly antagonistic, theoretical standpoints will cause, at least, confusion. Accepting Peirce's exemplary suggestion that the designation of concepts should be the object of an Ethics, ${ }^{2}$ it is well worth retrieving his term 'pragmaticism, ${ }^{3}$ which he once adopted, to distinguish his conception of pragmatism from those that followed his creation in $1878 .^{4}$

In fact, the term 'pragmaticism' emerges well after the creation of the doctrine in Peirce's youth. The later development of Peirce's philosophy, which became increasingly realistic and strongly metaphysical, incorporated additional meanings to pragmatism, turning it into a consequence of the relationship between his three categories, definitively formulated after 1902, when he expounded his Phenomenology in final form. Peirce's pragmatism becomes a generalized relationship between the general and the particular, ${ }^{5}$ in which the expression practical consequences, stated in original proposition of the maxim in 1878, assumes an increasingly ontological meaning, necessarily extending the sphere of human conduct to the conduct of all real objects. ${ }^{6}$ This extensionality of the concept of pragmatism derives, in fact, from the categorial symmetry ${ }^{7}$ between the phenomenological and ontolog-ical spheres, fundamental for the conception of Semiotics as a science that conceives meanings beyond human language.

6 Peirce's mature philosophy comprises a system of interlacing ideas, suggesting a nonfoundationalistic hierarchy between its diverse disciplines, notwithstanding such system being concerned with genetic issues, such as his conception of cosmogenesis. ${ }^{8}$ 
7 Rorty shares the tradition dating back to Nietzsche, as well as the majority of philosophers who strongly refute metaphysics - anti-essentialists, as they call themselves. ${ }^{9}$ However, among the many possible questions, it should be asked of an instrumentalist or utilitarianist pragmatist whether theological metaphysics, for instance, as a source of beliefs of common sense, should be the object of such radical rebuttal. Should not these beliefs be somehow considered, for their utility to human life, comforting men in their inexorable finitude before the hard impact of facts, bringing some hope of life to the destitute? Would this consideration not suffice to admit a sense of religiousness as something 'pragmatic'? Is there not, deep down in the radical rebuttal of theological metaphysics, not so much an epistemic issue as Kant put it, but rather a reaction against religious institutions that have historically imposed, to an extremely human tendency, viz., an attraction to transcendence, social habits and a morality associated with the exercise of power? Why are the two features, namely, the utilitarian experience and the metaphysical refutation, not set aside here, rather than tossing both out, the bath water and the baby, as popularly said? Seemingly, this issue brings a specter of reproach: some things are useful; others do not seem allowed to be. Could this propensity toward transcendence not also be merely poetic? Is conduct not pragmatically characterized on seeing Nature sacralized by a pantheistic conception of divinity - an opening for a silent and transcendental dialogue with each natural being? Why should this potentially poetic baby be tossed together with the dirty water of the moral dogmatism that restrains the human erotic impulse? Are not 'redescriptions,' understood as a deeper rereading of the diversity of facets that human experience undergoes, applicable here ${ }^{10}$

In my view, questions such as those are well worth asking. Deflating philosophy to the extreme may involve suppressing from it vital components that keep it alive. Perhaps this is Rorty's strategy: once anorexic, it can be replaced by literature.

\section{On the Concepts of Representation and Truth (Theses $A$ and $B$ )}

9 Rorty sees the concept of representation invariably associated to an external world endowed with ultimate essences, which it should mirror. He does not acknowledge any utility of that concept for human purposes. I believe, however, that this concept requires and I here apply again an expression dear to neopragmatists - redescription. This redescription would seek precisely to understand 'representation' within a criterion of meaning acknowledged by neopragmatism, namely, through its utilitaristinstrumentalist angle.

10 Primarily, it is necessary to 'redescribe' the world, ${ }^{11}$ of which the alleged 'representation' would be the mirror. Rorty invariably refers to a near pathetic intent of representationists toward a precision derived from a determinist world view, such as that outlined in Enlightenment. This view, however, has long broken away from contemporary science and the philosophies more apprised with its history. For a long time ontological determinism has ceased to be the hope not only of those who make science, but also of those who make it a metalanguage, namely, the epistemologists. Nevertheless, in various passages of his works, ${ }^{12}$ Rorty insists in attributing such a determinist view to representationists, as if wishing to adopt a convenient general strategy to discredit his 
adversary, who would be nurturing a world view derived from a belief in an all-foreseeing mathematical God in his project, remaining for man to discover what final laws, with a status of divine essences, were thought by Him. It would be fitting to ask why the right of vocabulary change is not granted to representationists. They would say that no respectable science would expect a determinist behavior from its objects, ${ }^{13}$ finding it natural to obtain a dispersion of results capable of being dealt with statistically through probability functions.

11 Why then would the term representation be justified for a theory? If, on the one hand, representation means an exact, mirroring, image of particular objects, human knowledge would have no utility, according to the valuation criterion adopted by neopragmatism. Alternatively, on the other hand, if representation is associated with final, fixed essences, it must also be agreed that no utilitarian function would be found in it. However, let us reformulate the concept of representation as a theoretical prediction of future conduct of its objects..$^{14}$ I believe that this function of representations, namely, to anticipate the future conduct of its objects, characterizes what Peirce meant with he claimed that the meaning of a positive theory lies in the future,,$^{15}$ namely, in its capacity of foreseeing the future course of acts. Here, incidentally, when we refer to 'objects' or 'facts,' we are faced with Rorty's suggestions that we should avoid these expressions, altering our vocabulary. Notwithstanding his acknowledgement of the utilitarian function of the predictability of theories, he forbids philosophy to speculate on the reason for the success or failure of such predictions, as if such speculation were ultimately guided by the pretense of discovery of concealed essences or realities. Here, I believe, lies the crux of the matter of representation and truth, as viewed by neopragmatism. To Peirce's pragmaticism, to represent means the primary function of our rationality in predicting what may occur in the future course of facts, and to guide our own behavior by the unveiling of the theories on what has not yet happened. To neopragmatism, representation embodies in its concept a static world-view, permeated with non-human entities, concealed metaphysical essences and other ghosts more commonly associated to a theological determinism. Applying the vocabulary used by neopragmatism, if we deflate the objects of representations from this anachronistic view of a theological determinism, incidentally suggested by Rorty for the sake of argumentative strategy, I suppose, then representation would be simply associated to objects endowed with habits of conduct, ${ }^{16}$ the knowledge of which is of extreme utility to us to plan how we should act to accomplish our purposes. But, viewed under an indeterminist light, a world endowed with randomness would emerge from that alleged Rortyan mirror as extremely clouded, incorporating this metaphor to another formulated by Popper (1972) in his brilliant work 'Of Clouds and Clocks, ${ }^{17}$ and such a world image could not be associated with any precise theory. I believe, however, that instead of trying to save this metaphor about the mirror, it would be much better to break it once and for all, fearless of what tragedy could befall philosophy in the next seven years, considering that Rorty always seems to keep mystics and believers of a reality essentialized by something non-human ${ }^{18}$ under the focus of his criticisms. The conceptual inutility of the mirror metaphor is distinguished by the fact that no clear image can be seen in it, given the indeterminate nature of the object. In spite of this indetermination, the positive theories may be perfectly classified by their adherence capacity between the course of facts and the predictions of those theories. This concept of adherence, common in factual sciences, would be justified by a conception of structural correspondence between the rule of conduct that subsumes facts in its phenomenical manifestation and its theoretical representation, notwithstanding how fallible ${ }^{19}$ all our affirmations on the world might be. 
We refer here to the Peircean conception that all our positive theories are fallible, not only associated with an indeterministic conception of world, but also linked to the randomness seen in human actions.

Clearly, then, theories that show good adherence to the course of facts may be considered true, without being a definite truth or associated with anachronically metaphysical determinisms. I would suppose that a highly cultured scientist would certainly refuse to acknowledge his theories as mere useful tools, but would rather say that many of them are true, albeit admitting that better theories - meaning more adherent $-{ }^{20}$ could emerge, and that those regarded today as possessing good adherence could lose this quality, as a result of the discovery of new phenomena.

Obviously there is a radical difference between what pragmaticism sees as a true theory and what Rorty states is a useful theory. Pragmaticism possesses a necessary realistic presupposition - not a realism that is so called for admitting the existence of an external world of objects independently of what we say about them, thus contrary to a subjectivist idealism. A pragmaticist realism proposes the hypothesis that the world contains habits of conduct, namely, general rules associated to the regularity seen in particular events. This hypothesis is useful to explain the reason why some theories are adherent and others not, thus redeeming the concept of fallible truth.

There are historical reasons that induce us to suppose the existence of an evolution of human knowledge, a growth in our repertoire of adherent theories. Peirce adopts, concomitantly, an evolutionist cosmology in which real thirdness grows in the universe, in tandem with a constant insertion of the diversity that complexifies it. The pragmaticist hypothesis that investigation tends toward a final agreement of opinions is solely based on that evolutionist conception, representing an asymptotic growth tendency of the Peircean category of thirdness. This brief synthesis of the evolutionary intertwinement that both epistemology and ontology have in Peirce's philosophy, seeks only to refute Rorty's affirmation that Peirce would have claimed that investigation tends to find a finished reality of essences that would constitute its purpose. ${ }^{21}$ Similar to many other opinions of Rorty about the history of philosophy, this point of Peirce's philosophy would require a redescription whose target would be to eliminate this ubiquitous mysticaltheological nature that Rorty attributes to all those who speak of some reality beyond the language practiced by mankind.

\section{On Discovery and Invention (Theses C and D)}

Scientific theories, according to neopragmatists, are inventions that scientists create in order to have problem-solving 'tools' at their disposal. It stands to reason that, although theories regarded as true are useful, it does not necessarily follow that 'utility' is the guiding criterion for the establishment of a theory for which there is a catholic consensus on its truthfulness. Also, if a general structure that regulates the conduct of objects their habits, to use an expression employed by pragmaticists - is not discovered, then there is no way of explaining why some theories are adherent and others not. True theories are, in general, adapted to empirical data, under the presupposition that its predictive form retains the adherence verified experimentally.

Ultimately, the issue refers to the nominalist or realist stance before the world. Peirce's scholastic realism ${ }^{22}$ presupposes that there are laws that act on the objects that we 
endeavor to know, albeit being laws with varying degrees of cloudiness, according to Popper's metaphor.

Evidently, based on a nominalist approach, Rorty will not consider any differentiation between invention and discovery, since language has the status of tools that must work.

Should we, however, wish to reflect why they work, we will be in touch with "things greater and more powerful than everyday human existence." ${ }^{23}$

Indeed, to confuse discovery with invention elicits, tacitly, in my view, two ominous aspects for philosophy, namely, non-acknowledgment of the otherness of the world, which leads to an indistinction between reality and fiction. For no other reason, Rorty proposes matter-of-factly the replacement of philosophy by literature, after suppressing from the former all contact with world otherness.

\section{Mediation and Redescription (Theses E, F)}

Rorty also does not admit that language is mediation between subject and object, due to the fact that, to him, language has an autonomy that turns his neopragmatism, according to some commentators, into a type of "linguistic idealism. ${ }^{24}$ In fact, it seems that Rorty considers the role of mediation as less noble for language, seeing that it would have a role of representation of the characteristics of the object, having to submit to it in order to acquire meaning. In actual fact, this denial of the mediating role of language derives, to my mind, from the early theses based on the nominalism that characterizes neopragmatism.

21 Description and redescription are Rortyan concepts that replace the concepts of truth and representation, as they are seen, of course, by neopragmatism. There are, however, serious problems that neopragmatism would encounter when one resorts to the pragmaticist thesis that the meaning of a positive theory is its esse in futuro or, as mentioned before, its predictive power. How, then, to describe the future? Can description and inference, here, be considered equals? The word describe, consistent with nominalism, could not be applied to general objects, but solely to particular objects. Therefore, under this vocabulary, how does the predictive function of theories work? How, in this case, can 'redescription' be understood? Would it be the formulation of ad hoc hypotheses on what did not work out?

22 Here I see the deepest contradiction in the neopragmatist claims. They defend language as a tool, but not at all connected with any representation of a real world. On the other hand, representation of reality, in the sense of being constituted of positive theories, is the only available way we have to predict its future course - without this, language would be a worthless tool, and therefore its required role of being only a useful instrument to deal with human experience would inexorably fail. In any sense that language is successfully predictive of the course of experience, then it is somehow committed to the representation of the conduct of its real object. And such representation has nothing to do with mirrors - indeed a metaphor that could be useful if understood as related to reflection, whose ancient root, the Latin refletire, would fairly describe the hard work of the human mind to correct theories based on the external images formed by the human actions they have induced. In fact, this would be a rich metaphor, namely, mirror as referring to the reflexive dialogue between the inner side of our thoughts and the 
external side of our actions, in a self corrective process. This, by the way, is the true core of Peirce's pragmatism ${ }^{25}$ from which neopragmatism passes quite far away.

\section{On Community and Solidarity (Thesis G)}

\section{V.1}

I recall when, still an engineering student during the late 60s, a professor of the physics of relativity suggested to lower-income students to purchase the Russian edition of a book on the theme of the course, which cost a fifth of the American price. Obviously subsidized by the Soviet Government, the book dealt with the same physics as the considerably more expensive book published in the United States. Even at that time, this made me wonder why two ideologically dissimilar societies that were then competing for who would have the greatest power to destroy the world, ${ }^{26}$ promoting a frightening and tense cold war, could produce the same physics? Could there not be a leftist, revolutionary Physics, with descriptions and redescriptions invented by soviet physicists, seeking to distinguish themselves from a bourgeois, capitalist and decadent science?

Nevertheless, the truth was that physicists from the western and eastern blocs, constituted a community of researchers above ideological, cultural and historical idiosyncrasies. Is this fact not proof that this community had a common base reaching beyond a mere sharing of opinions derived from conversation and creative use of language? Were theories not guided by a similar dialogue with world otherness constituted by the objects of common experience, which imposed an equal set of theories accepted as true? In this case, if language conferred form to the world, why were not distinct forms, customary to societies who affirmed themselves by establishing among them all kind of distinctions, made possible?

\section{V.2}

The force of the otherness of facts, I hold, is the only base on which to settle a community, whether scientific or comprising citizens of some society. To reduce the possibility of a community to free democratic conversation, as the neopragmatist school does, is to presuppose, on the one hand, that the agreements that supposedly reach a common good be spontaneously extendable to the whole of society and that, on the other hand, be effectively complied with.

Various counter arguments may be raised against this neopragmatist position. As far as the extendibility of an accord to the totality of mankind is concerned, one may ask whether, in defense of the power of language to constitute communities, there is not an indispensable, albeit tacit, admission of an ethics of good feelings, sufficiently fragile I suppose, on which to lay the hope of human solidarity. On the other hand, a presupposition that reciprocal agreements are complied with requires an inability to lie and a capacity to forgo self-interests, in order that such compliance does not deviate from its course.

Pragmatism, in its Peircean inception, had as its golden rule a logical commitment between thought and action, a commitment of coherence that would finally confer meaning to discourse, to language. For this reason, it had, along with its logical-semantic dimension, an ethical dimension: action would materialize in the outer plane open as 
common experience, by which the truth of statements is either affirmed or denied. Under this conception, language lies solely within the dimension of the inner world of men, namely, the world of possibilities that can influence their actions. I hold that pragmaticism, ultimately, is a relationship of commitment between inner and outer worlds, in which acting is how an indeterminate generality of concept is determined, within a theater of reactions open to common experience.

To base humanity's shortcomings on democratic conversation is to scorn the instance where language, which has facticity as reference, may appear as fact, namely, human action that, in the pragmaticist view, is the way in which language emerges from its inner world and enters the outer world. While not doing so, basing its accords only on itself, on its inventions of world, on the sophistic power of persuasion through rhetorical seduction, I fear then the possibility of a reign of terror, of domination, as history often shows, following thus an opposite path to that presupposed by neopragmatists.

Naïve and uninformed is, at best, the supposition that the model of American democracy is ideally exportable to other societies of deeply distinct historical backgrounds, culturally dissimilar to it. One must, however, acknowledge that democracy is a necessary condition for a society that theoretically respects individual citizen rights. However, it does not follow that democracy suffices in a reciprocal society, as required by Rorty.

We agree that Rorty's project of a solidary society, as described by him, is utopian. This project, however, would not be utopian because of an ideality in communion with other social utopias that the history of ideas records, but rather because it is indeed based on the naïve hypothesis that the solidarity and good will of American society would be disseminated throughout the planet, by the freedom provided by democracy. Would it suffice for men to converse and exchange vocabulary when it lost its utility? Could one also ask why would men be sympathetic, forming a community of common interests solely because they are free and share a language? If American society reveals an appearance of reciprocal community, would it not be derived from a specific culture, from a historical contingency that is not the same in other societies? There are many democracies in emerging nations in which the political class is really solidary, but only amongst its members, promoting and practicing a cronyism that cloaks privileges, corruption, nepotism and other illicit acts. Solidarity, as such, is a fact in any society, although confined to interest groups.

31 Solidarity sustained on an idea of common good would require, on the one hand, the effective individual will of each of its members toward this idea and, on the other hand, a culture in which the acknowledgment of ethical values placed in its practice represented a community habit.

32 A society judges its politicians pragmatically, namely, by the degree of logical consistency between discourse and conduct. A philosopher's abilities would not be required here: the common citizen is not satisfied with what a public figure declares. Having voted for him, for his promises, this citizen will demand such consistency: effective conduct will have the final word - the manifest form of language, open to the factual experience of everyone.

\section{Conclusion}

I recall a creative passage, attributed to Einstein: 
Theory is when you know all and nothing works. Practice is when all works and nobody knows why. In this case we have put together theory and practice: nothing works [...] and nobody knows why! 'exchange of vocabularies.' We must understand what caused them, searching for the general rule that governs the path of otherness in relation to which our actions were illfated. Language and theories as mere tools do not grant this status of generalization that we seek: we want to learn beyond a mere empiricism that allows for contingent solutions, as if we were strolling through a stretch of an exponential function and had taken it as linear: soon a gamut of new experiences would denounce this redescription as a naïve illusion. Failure and error force us to a more wide-ranging dialogue, beyond our own language: toward objects taken in their integrity, namely, in their unveiling as existence open to experience and in their habit of being that surpasses the contingency of mere particular existence.

37 There are many profound ideas that the history of philosophy has discussed, and which Rorty seems to ignore: they orbit in this interaction between theory and experience, involving the general and the particular interplay; in the conditions of apprehension and perception of generality in contingency; in language as a network that captures aspects of the real, turning them into objects of reflection, with the necessary consideration of their otherness.

38 I cannot see why, in Rorty's words, 'the mysterious and concealed reality of the world, much greater than us, humans' can be more barred to us than that which conceals the innerness of men. On the contrary, world facticity conceals nothing in an immediate manner other than what appears mediately, cognizable through inference. However, if we consider that, pragmatically, language is only revealed in action as its unveiled aspect, without that instance in which it is exteriorized as determination, it is meaningless. This is a requirement of pragmaticism, that sees in the action the outer aspect of thought and, consequently, of language. The conversation of men is, no doubt, necessary, but for pragmaticists it is insufficient for something as important as human solidarity to support itself.

39 The realistic conversation of pragmaticists goes beyond human language. Semiotics is the science that considers that men not only converse among themselves, but also reflexively with the actions and the world facts with which they interact, and which, incidentally, is also endowed with a language constituted by an interchange of signs and meanings present in Nature. Nominalism could only lead to an anthropocentrism, and this philosophical approach has been responsible for us to consider Nature as something foreign to humankind, something devoid of language. ${ }^{27}$ More than ever, had Peirce had a close relationship with Rorty, he would resume his proposal to change the name of pragmatism to pragmaticism, leaving the former to a doctrine that has nothing to do with

European Journal of Pragmatism and American Philosophy, V-1 | 2013 
his philosophy. Under these circumstances, he would surely say: we, pragmaticists, absolutely refute what you, neopragmatists have been saying.

\section{BIBLIOGRAPHY}

AltShuler B., (1978), “The Nature of Peirce's Pragmatism," Transactions of the Charles Sanders Peirce Society, 14, 3, 147-75.

BOLER J. F., (1963), Charles Peirce and Scholastic Realism: A Study of Peirce's Relation to John Duns Scotus, Seattle, University of Washington Press.

BRANDOM R. (ed.), (2000), Rorty and His Critics, Oxford and Cambridge, Mass. Blackwell.

BRODSKY G., (1982), "Rorty's Interpretation of Pragmatism," Transactions of the Charles S. Peirce Society, 17, 4, 311-38.

HAACK S., (1993), Evidence and Enquiry: Towards Reconstruction in Epistemolog, Oxford and Cambridge, MA, Blackwell.

ноoкway C., (2005), “The Pragmatist Maxim and the Proof of Pragmatism," Cognitio, São Paulo, 6, $1,25-42$.

IBRI I. A., (2009), "Reflections on a Poetic Ground in Peirce's Philosophy," Transactions of the Charles S. Peirce Society, 45, 3, 273-307.

IBRI I. A., (2011), “Semiotics and Epistemology: The Pragmatic Ground of Communication," in Rosa M. Calcaterra, ed., New Perspectives on Pragmatism and Analytic Philosophy, Amsterdam, Rodopi, 71-82.

IBRI I. A., (2010), “Peircean Seeds for a Philosophy of Art," in Haworth K., Hogue J., \& Sbrocchi L. G., (eds.), Semiotics 2010. The Semiotics of Space, New York, Legas Publisher, 1-16. IBRI I. A., (2012), “Choices, Dogmatisms and Bets,” Veritas, PUCRS, 57, 2, 51-61.

FORSTER P., (2003), "The Logic of Pragmatism: A Neglected Argument for Peirce's Pragmatic Maxim," Transactions of the Charles Sanders Peirce Society, 39, 4, 525-45.

FORSTER P., (1997), “The Logical Foundations of Peirce's Indeterminism,” in J. Brunning \& P. Forster (eds.), The Rule of Reason: The Philosophy of Charles Sanders Peirce, Toronto, University of Toronto Press.

LISZKA J. J., (2009), “Re-Thinking the Pragmatic Theory of Meaning," Cognitio, São Paulo, 10, 1, 61-79.

MARGolis J., (2007), “Rethinking Peirce's Fallibilism," Transactions of the Charles Sanders Peirce Society, 43, 2, 229-49.

PEIRCE Charles S., (1931-58), Collected Papers of Charles Sanders Peirce, Vols. I-VIII, Charles Hartshorne, Paul Weiss, and Arthur Burks, eds., Harvard University Press (referred as CP). PEIRCE Charles S., (1992-98), The Essential Peirce. Selected Philosophical Writings vols. 1-2, N. Houser et. al. (eds.), Bloomington, Indiana University Press (referred as EP). 
PEIRCE Charles S., (1976), The New Elements of Mathematics by Charles S. Peirce., 4 vols, Carolyn Eisele (editor), The Hague, Mouton (referred to as NEM).

RORTY R., (1979), Philosophy and the Mirror of Nature, Princeton NJ, Princeton University Press (referred as PMN).

RORTY R., (1982), Consequences of Pragmatism, Minneapolis, University of Minnesota Press (referred as $\mathrm{CP}$ ).

RORTY R., (1989), Contingency, Irony, and Solidarity, Cambridge, Cambridge University Press (referred as CIS).

RORTY R., (1991), Objectivity, Relativism, and Truth: Philosophical Papers, Volume 1, Cambridge, Cambridge University Press (referred as ORT).

RORTY R., (1991), Essays on Heidegger and Others: Philosophical Papers, Volume 2, Cambridge, Cambridge University Press (referred as EHO).

RORTY R., (1998), Truth and Progress: Philosophical Papers, Volume 3, Cambridge, Cambridge University Press (referred as TP).

RORTY R., (1999), Philosophy and Social Hope, Harmondsworth, Penguin Books (referred as PSH).

TURLEY P., (1977), Peirce's Cosmology, New York, Philosophical Library.

\section{NOTES}

1. As it appears, exemplarily, in the well-known Philosophy and the Mirror of Nature, Princeton, NJ, Princeton University Press, 1979, 10.

2. See "Ethics of Terminology" in CP, 2. 219-226 / EP2 263-266.

3. CP 5.414 / EP2 334-335. In this paragraph, Peirce did write: "So then, the writer, finding his bantling 'pragmatism' so promoted, feels that it is time to kiss his child good-by and relinquish it to its higher destiny; while to serve the precise purpose of expressing the original definition, he begs to announce the birth of the word 'pragmaticism,' which is ugly enough to be safe from kidnappers To show how recent the general use of the word 'pragmatism' is, the writer may mention that, to the best of his belief, he never used it in copy for the press before today, except by particular request, in Baldwin's Dictionary. [See 1-4.] Toward the end of 1890, when this part of the Century Dictionary appeared, he did not deem that the word had sufficient status to appear in that work. [But see 13n.] But he has used it continually in philosophical conversation since, perhaps, the mid-seventies."

4. Peirce, "How to Make Our Ideas Clear," Popular Science Monthly 12, 286-302; CP-5, 388-410 / EP1 124-141.

5. In CP-5.170, Peirce claimed: "The validity of induction depends upon the necessary relation between the general and the singular. It is precisely this which is the support of Pragmatism." See interesting approaches of pragmatism in Altshuler (1978), Forster (2003), Hookway (2005) and Liszka (2009).

6. I considered this ontological consequence of pragmatism in, for example, Ibri (2011).

7. 7 I have used the expression "categorial symmetry" due to the indifferent validity of Peirce's three categories for subject and object domains. See, for instance, Ibri (2012).

8. See on this subject Turley (1977).

9. An example of Rorty's anti-essentialism can be found in his "A World without Substances and Essences" Rorty (1999). 
10. 1My claim is that poetic experience can be considered from the point of view of Peirce's pragmaticism, however fully connected with his ontology. See Ibri (2009) and (2010).

11. Notwithstanding 'world' being what is most lacking in the neopragmatism discourse.

12. See his insistence on the concept of 'exact representation' in, for instance, ORT, 99 and PMN, 377.

13. In CP 1.9, we read "In those sciences of measurement which are the least subject to error metrology, geodesy, and metrical astronomy - no man of self-respect ever now states his result, without affixing to it its probable error; and if this practice is not followed in other sciences it is because in those the probable errors are too vast to be estimated." See also NEM-III/2, 897.

14. In CIS, 5-7, Rorty criticizes the conception of language as mediation between subject and object.

15. In CP 5.427/ EP 2.340, Peirce said "The rational meaning of every proposition lies in the future. How so? The meaning of a proposition is itself a proposition. Indeed, it is no other than the very proposition of which it is the meaning: it is a translation of it. But of the myriads of forms into which a proposition may be translated, what is that one which is to be called its very meaning? It is, according to the pragmaticist, that form in which the proposition becomes applicable to human conduct, not in these or those special circumstances, nor when one entertains this or that special design, but that form which is most directly applicable to selfcontrol under every situation, and to every purpose. This is why he locates the meaning in the future time; for future conduct is the only conduct that is subject to self-control."

16. In many passages, Rorty encourages the adoption of creative vocabularies. See, for example CIS, 20.

17. Popper (1972), "Of Clouds and Clocks," in Objective Knowledge, Oxford, Clarendon Press, 206-55.

18. See, exemplarily, TP, 226.

19. Margolis (2007) and Foster (1997) are good examples of interesting discussion of Peirce's fallibilism.

20. I would suggest that adherence actually is a better term to use instead of truth, as the latter somehow induces minds not acquainted with the concepts of indeterminism and fallible knowledge, as claimed by Peirce, to think on fixed essences, like Rorty insistently does. Truth, then, would be only used under the consideration that theories are fallible and, consequently, they must be changed whenever experience imposes such change in any demanded degree.

21. ORT, 131.

22. At this point, scholars should remember the classical and pioneering work by Boler (1963).

23. EHO, 28.

24. Such as mentioned by Brandom (2000: 160).

25. In CP 8.272, we can read such reflexive aspect of Peirce's pragmatism: "Pragmatism is correct doctrine only in so far as it is recognized that material action is the mere husk of ideas...But the end of thought is action only in so far as the end of action is another thought."

26. I recall that the soviets showed their concern for their inferiority in being capable of destroying the planet only 20 times (!) over, while the Americans were capable of doing it 22 times (!).

27. "The world does not speak. Only we do" (CIS, 6). 


\section{ABSTRACTS}

There are significant differences between the neopragmatism as formulated by Rorty, based on James' and Dewey's pragmatism, and what Peirce, in order to distinguish his own approach from the last two thinkers, called pragmaticism. I take in this paper the concept of solidarity as a focus, from which those differences will be implied, albeit many other points could be chosen. I highlight that the usual Rorty's sentence beginning with 'we pragmatists...' shall necessarily exclude Peirce. Exemplarily, I could mention the concepts of representation, which for Peirce has nothing to do with mirror, and of truth that, for him, also has no relation at all with fixed essences. Those differences will not only mark a very clear border between the two concepts of pragmatism, but also will question how the idea of community can be supported only by dialogical agreements, without the anchor of common open human experience. Pragmaticism and neopragmatism differ not only regarding their specific range of philosophical problems but, moreover, on what kind of problems they really consider as genuinely philosophical.

\section{AUTHOR}

\section{IVO ASSAD IBRI}

Center for Pragmatism Studies, Pontifical Catholic University of São Paulo - Brazil

ibri[at]uol.com.br 